\title{
MANIFESTASI BEHÇET DISEASE YANG PARAH DAN KOMPLIKASI PERAWATANNYA DALAM RONGGA MULUT (Laporan kasus)
}

\author{
Liza Meutia Sari*Titiek Setyawati** \\ Departemen Ilmu Penyakit Mulut, Fakutas Kedokteran Gigi, Universitas Indonesia \\ J1. Salemba Raya No.4 Jakarta Pusat. Telp. (021)2303257
}

\section{Keywords: \\ Behçet's disease, manifestation, severity, lichenoid lesion}

\begin{abstract}
Behçet's Disease (BD) is a multisystem inflammatory disorder characterized by recurrent oral-genital ulcers, ocular inflammation and frequently involves the joints, skin, central nervous system and gastrointestinal tract. We reported a case of severe $\mathrm{BD}$ in 30 years old male patient with oral-genital ulcerations and ocular involvement. He had suffered from the disease since twelve years ago and ocular involvement has lead to blindness of the right eye. Eye drop treatment for eight years, was suspected to cause lichenoid lesion on the buccal mucosa. Management of this patient included the application of topical steroid, $1 \%$ povidone iodine and oral hygiene promotion. We concluded that disease condition, poor oral hygiene, disability and less compliance of the patient could slowed the acceleration of lesions healing. Elimination local exacerbating factors and a good coordination between dentist-patient and among medical team work are required to achieve the optimal recovery and to minimize complication of its treatment in the oral cavity
\end{abstract}

\section{Pendahuluan}

Behçet's Disease (BD) merupakan suatu peradangan multisistem kronis yang ditandai oleh ulserasi yang hilang timbul pada rongga mulut, alat kelamin, mata dan umumnya melibatkan sendi, kulit, sistem saraf pusat dan saluran pencernaan. ${ }^{1-6}$ Selain ulserasi rongga mulut, manifestasi klinis di organ lain sangat bervariasi pada tiap populasi yang berbeda. Hal ini berkaitan dengan adanya pengaruh genetik terhadap timbulnya serta perkembangan penyakit. ${ }^{7}$ Etiologi BD masih diperdebatkan hingga saat ini, namun hipotesis mengenai patogenesisnya sudah banyak diteliti yakni BD timbul akibat adanya respon peradangan yang 
dipicu oleh agen infeksius pada tubuh pejamu dan dipengaruhi oleh genetik tertentu. ${ }^{1}$ Walaupun BD merupakan penyakit yang insidensinya termasuk sangat jarang terjadi di seluruh dunia, namun penyakit ini banyak ditemukan secara endemik di sepanjang jalur sutera dari Asia hingga Mediteranea. ${ }^{8}$

Sampai saat ini, BD masih merupakan tantangan bagi berbagai aspek dalam bidang kedokteran dan kedokteran gigi seperti usaha penegakan diagnosis seta pemilihan terapi yang tepat. ${ }^{2}$ Laporan kasus ini menggambarkan BD dengan manifestasi pada rongga mulut, alat kelamin dan mata pria berumur 30 tahun, serta komplikasi perawatannya dalam rongga mulut. Perkembangan penyakit telah berlangsung selama dua belas tahun dan telah menyebabkan kebutaan mata kanannya.

\section{Tinjauan Pustaka}

Behçet's disease (BD) atau Behçet syndrome tergolong penyakit vaskulitis sistemik, karena terjadi keterlibatan pembuluh arteri dan vena di berbagai organ tubuh. ${ }^{1}$ Manifestasi BD dapat terjadi pula pada berbagai sistem organ di antaranya trombosis, gangguan neurologis (keterlibatan sistem saraf pusat parenkim dan hipertensi intrakranial), gangguan kardiovaskular (aneurisma arteri dan vaskulitis pembuluh darah kecil), ulserasi intestinal serta polikondritis. ${ }^{1,4,9}$ Penyakit ini sebagai suatu kesatuan penyakit, pertama kali digambarkan oleh dokter ahli penyakit kulit yang berasal dari Turki bernama Hulusi Behçet pada tahun 1937 yang menyebutnya sebagai "ulser aftosa rekuren, ulser genital dan uveitis-hipopion". $3,5,10$ Prevalensi BD di dunia sangat bervariasi tergantung pada etnis dan daerah geografis tertentu. ${ }^{5,8}$ Umumnya BD terjadi di negaranegara yang berbatasan dengan rute jalur sutera seperti Jepang, Korea, Cina, Irak, Iran dan Turki. ${ }^{5}$ Prevalensi BD tertinggi di dunia adalah di kota Anatolia, Turki dengan jumlah 370 pasien di antara 100.000 jiwa. $^{11}$ Sedangkan prevalensi terendah adalah di Eropa utara dan Amerika Serikat dengan jumlah 0,1 hingga 7,5 pasien diantara 100.000 jiwa. ${ }^{5,11}$ Behçet's disease dapat terjadi pada semua golongan usia, terutama dekade dua dan tiga dengan perbandingan yang sama antara pria dan wanita, namun hal ini masih tergantung pada lokasi geografis. $^{8,12}$ Keparahan penyakit umumnya dikaitkan dengan onset gejala yang timbul pada usia muda dan jenis kelamin pria. ${ }^{6,8,13}$

Hingga kini Etiopatogenesis BD belum jelas dan masih dilakukan penelitian untuk mengetahui hal ini, namun agen infeksius (infeksi virus dan bakteri), mekanisme imun (proses autoimun) dan faktor genetik (HLA$\mathrm{B}^{*}$ 51) dianggap memiliki peran penting dalam patogenesis BD. ${ }^{6}$ Diagnosis BD ditegakkan berdasarkan kriteria klinis yang ditetapkan oleh "International Study Group for Behçet's Disease (ISGBD) tahun 1990 (Tabel 1). ${ }^{14,15}$

Tabel 1. International Study Group for Behçet's Disease (ISGBD) tahun $1990^{14,15}$

\begin{tabular}{|c|c|}
\hline Ulserasi rongga mulut rekuren & $\begin{array}{l}\text { - } \\
\text { - } \quad \text { Uftosa minor } \\
\text { berdasiarkan laporan pasien } \\
\text { - } \quad \text { Rekurensi terjadi minimal } 3 \text { kali dalam } 12 \text { bulan. } \\
\text { Ditambah dua kriteria: }\end{array}$ \\
\hline Ulserasi alat kelamin rekuren & $\begin{array}{l}\text { Ulserasi aftosa genital rekuren atau adanya jaringan sikatrik, terutama pada pria, sesuai dengan } \\
\text { temuan klinis oleh dokter ahli atau berdasarkan laporan pasien. }\end{array}$ \\
\hline Lesi pada mata & $\begin{array}{cl}\text { 1. } & \text { Uveitis anterior } \\
\text { 2. } & \text { Uveitis posterior } \\
\text { 3. } & \text { Adanya sel dalam "vitreous humor" pada pemeriksaan slit lamp } \\
\text { Atau: } & \\
& \text { Vaskulitis retina yang ditentukan oleh dokter ahli penyakit mata }\end{array}$ \\
\hline Lesi pada kulit & $\begin{array}{l}\text { 1. Erythema nodusum-like lesion yang ditentukan oleh dokter ahli atau berdasarkan } \\
\text { laporan pasien } \\
\text { 2. Pseudofolikulitis } \\
\text { 3. Lesi papulopustular } \\
\text { Atau: } \\
\text { Acneiform nodules yang konsisten dengan BD, telah ditentukan oleh dokter ahli dan pada pasien } \\
\text { yang telah melewati masa dewasa yang tidak sedang menjalani perawatan dengan kortikosteroid. }\end{array}$ \\
\hline Tes patergi positif & $\begin{array}{l}\text { Papula eritematus }>2 \mathrm{~mm} \text { pada lokasi tusukan yang timbul } 48 \text { jam setelah aplikasi jarum steril, } \\
\text { ukuran } 20-22 \text { gauge, yang berpenetrasi ke bagian kulit tanpa vaskularisasi sedalam } 5 \mathrm{~mm} \text {, dibaca } \\
\text { oleh dokter ahli setelah } 48 \text { jam. }\end{array}$ \\
\hline
\end{tabular}


Liza Meutia Sari, Titiek Setyawati

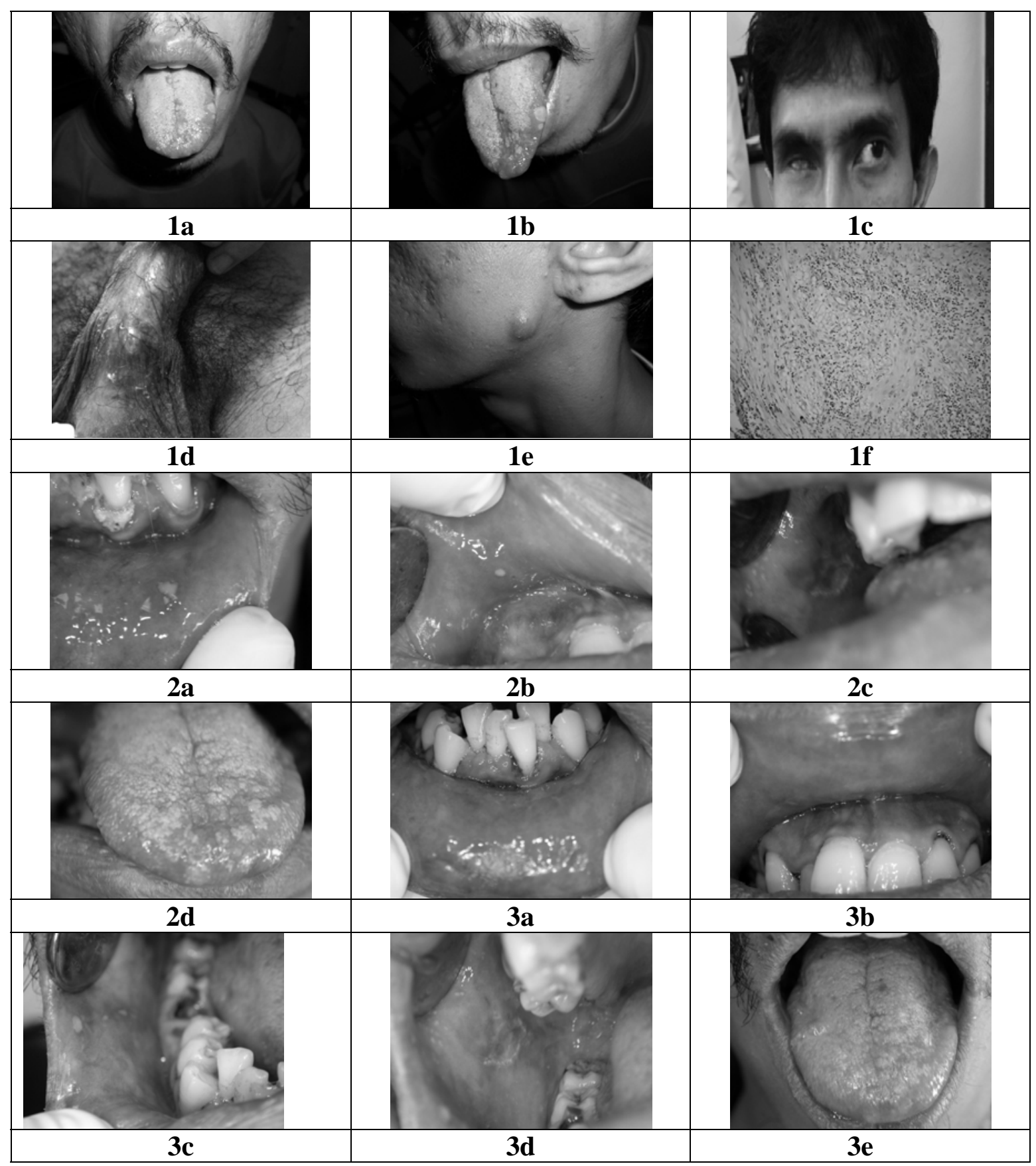


Perawatan BD meliputi perawatan lokal, sistemik atau tindakan bedah ${ }^{14}$ Obat yang diberikan diantaranya kortikosteroid, tetrasiklin, Anti Inflamasi Non Steroid (AINS), kolkisin, siklosporin A, siklofosfamid, interferon alfa-2a, metotreksat, antibiotika, talidomid, dapson, levamisol dan pentoxifyline. ${ }^{6,14}$ Tindakan bedah dilakukan jika timbul aneurisma arteri. ${ }^{6}$

\section{Laporan Kasus}

\section{Resume bagian kulit kelamin RSUPN-CM}

Pada tanggal 24 Februari 2006 seorang pasien laki-laki berumur 30 tahun datang ke poli Penyakit Kulit Kelamin dengan keluhan luka dan nyeri di anus dan buah zakar sejak dua minggu yang lalu. Adanya luka-luka tersebut hilang timbul berulang sejak dua belas tahun yang lalu, juga terdapat sariawan rongga mulut yang muncul hampir tiap bulan dengan ukuran yang bervariasi (Gambar 1a-b). Pada awalnya terdapat beberapa bintil agak kemerahan sebesar biji kacang kedelai di buah zakar, penis, anus dan lipat paha yang jumlahnya bertambah banyak lalu pecah, mengeluarkan cairan bening atau kadang-kadang nanah (Gambar 1d). Luka di alat kelamin diobati sendiri dengan salep dan bedak salisil, dalam waktu sebulan luka-luka tersebut berkurang, namun tidak sembuh. Riwayat demam, sekelan, kelainan saluran cerna dan saraf, radang kelamin, buang air kecil nyeri atau bernanah disangkal.

Sejak tahun 1998 kedua mata sering merah namun tidak berair atau belekan. Tahun 2002, pasien berobat ke poli penyakit mata. Saat itu, diagnosis kerja pada bagian penyakit mata adalah visus OD 0 , OS 1/60, katarak matur ODS, uveitis sanata OS, riwayat glaukoma OD. Cyclocryotherapy (CCT) pada mata kanan dilakukan dua kali. Saat ini mata kanan sudah buta sedangkan mata kiri masih mampu melihat bayangan (Gambar 1c). Terkadang timbul bisul bernanah berulang di wajah (Gambar 1e). Diagnosis kerja yang ditegakkan adalah sindrom Behçet dengan infeksi sekunder. Diagnosis banding adalah herpes genital dan ulkus molle. Terapi yang telah diberikan adalah kompres PK 1/100.000 pada lesi di kulit, klindamisin $300 \mathrm{mg}$ tiga kali sehari selama 1 minggu, aplikasi pasta triamcinolon acetonide $0,1 \%$ dua kali sehari untuk lesi rongga mulut dan krem fluocinolon acetonide $0,025 \%$ untuk lesi di skrotum. Hasil pemeriksaan antibodi terhadap herpes simplex virus 2 (HSV-2) menunjukkan nilai IgG HSV-2 adalah 66,8 $(\mathrm{N}<22)$ dan IgM HSV-2 negatif.

Hasil pemeriksaan histopatologis menunjukkan ortokeratosis dan hiperplasia pada lapisan epidermis serta serbukan padat sel radang limfosit, histiosit, netrofil dan eusinofil perivaskular pada lapisan dermis. Ditemukan juga pembuluh darah dengan endotel membengkak, degenerasi fibrinoid disekitarnya dan ekstravasasi eritrosit (Gambar 1f). Kondisi ini tidak bertentangan dengan gambaran histologis sindrom Behçet. Pasien kemudian dikonsul ke bagian Penyakit Mata divisi InfeksiImunologi dan bagian Penyakit Mulut.

\section{Resume bagian penyakit mulut RSUPN-CM}

Pada tanggal 1 Mei 2006, seorang pasien laki-laki berusia 30 tahun, suku Batak-Karo, dikonsul dari Poli Kulit Kelamin dengan diagnosis kerja Sindrom Behçet untuk evaluasi dan tata laksana di bagian gigi dan mulut. Saat ini, pasien mengeluh timbul sariawan sejak tiga hari yang lalu. Pada lidah terdapat plak putih, erosi negatif. Pada mukosa bibir bawah terdapat erosi multipel. Terapi yang telah diberikan adalah kolkisin 0,6 mg dua kali sehari selama satu minggu. Pasien mengeluh sariawan muncul hilang timbul sejak duabelas tahun yang lalu, namun sariawan makin sering muncul sejak tiga tahun terakhir. Pada awalnya, timbul bintik merah atau luka bekas tergigit yang berubah menjadi sariawan pada bibir bawah lalu meluas ke langit-langit, lidah dan pipi bagian dalam. Sariawan muncul tanpa disertai demam. Saat ini, pasien hanya memakai salep kenalog yang diberikan dari bagian kulit sejak dua bulan yang lalu. Jika memakai salep tersebut, sariawan berkurang jumlahnya dalam waktu dua hari, namun muncul kembali di lokasi yang berbeda dalam rongga mulut. Pasien biasanya menyikat gigi sekali sehari yakni pagi hari. Riwayat sariawan berulang dalam keluarga disangkal. Pasien merasa stres karena merasa penyakit 
tidak sembuh-sembuh. Pasien tidak pernah meminum obat dalam jangka waktu yang lama, kecuali menggunakan obat tetes mata selama sepuluh tahun. Pasien tidak memiliki pekerjaan atau pengangguran.

Pada kunjungan pertama di Poli Penyakit Mulut, tampak keadaan umum pasien baik, namun pasien harus dipapah oleh ibunya karena sudah tidak mampu melihat dengan baik. Pada pemeriksaan ekstra oral dijumpai kelenjar limfe submandibula teraba, kenyal dan tidak sakit, tidak ada kelainan pada kelenjar limfe submental dan servikal, bibir tampak kering. Pada pemeriksaan intra oral ditemukan kebersihan mulut buruk, terdapat debris, kalkulus sub dan supra gingiva di seluruh regio disertai bau mulut. Margin gingiva hiperemis dan edema di seluruh regio. Ulser putih, dangkal, dikelilingi daerah eritem dengan bentuk tidak beraturan, ukuran 1 x $2 \mathrm{~mm}$ di mukosa labial bawah regio gigi 33 (Gambar 2a). Ulser putih, dangkal, dikelilingi daerah eritem, diameter $2 \mathrm{~mm}$ juga terdapat pada mukosa labial atas regio gigi 12 (Gambar 2b). Pada mukosa bukal kanan terdapat fordyce granule, hiperpigmentasi kehitaman disertai striae putih dan daerah yang atrofi, eritematus di regio gigi 46, 47 (Gambar 2c). Pada lidah terdapat coating putih tebal di seluruh dorsum dan fisur dangkal di median (Gambar 2d). Tidak terdapat kelainan pada palatum durum, molle, ventral lidah, dan dasar mulut.

Berdasarkan pemeriksaan subyektif dan obyektif, diagnosis yang ditegakkan saat itu adalah Sindrom Behçet, halitosis, suspek reaksi likenoid disebabkan dugaan pemakaian obat tetes mata selama sembilan tahun, gingivitis marginalis kronis generalisata, 18,16,37,36,46 radiks dan 17,15,47,48 iritasio pulpa. Saat itu, pasien diinstruksikan untuk menyikat gigi minimal dua kali sehari (pagi hari sesudah makan pagi dan malam hari sebelum tidur), berkumur dengan menggunakan obat kumur yang mengandung povidone iodine $1 \%$ dan penyikatan lidah. Untuk perbaikan kondisi intra oral, pasien dikonsul untuk tindakan pembersihan karang gigi, pencabutan gigi $18,16,37,36,46$, penumpatan gigi $17,15,47,48$, pembuatan gigi tiruan sebagian serta anjuran untuk memperbaiki posisi gigi yang berjejal. Pasien juga dianjurkan untuk melanjutkan pemakaian kenalog, namun diberikan instruksi pemakaian yang lebih terperinci.

Pasien kontrol delapan hari kemudian. Pasien merasa sariawan di bibir atas dan bawah sudah menghilang (Gambar 3a-b), namun empat hari yang lalu timbul sariawan baru di pipi kanan bagian dalam. Pasien sudah tidak menggunakan salep kenalog karena sulit mengolesnya dengan baik. Menurut pasien, luka di kemaluan sudah menghilang, namun biasanya dalam waktu dua minggu dapat timbul kembali. Pada pemeriksaan intra oral ditemukan tiga buah ulkus dangkal, bulat, dikelilingi daerah eritem dengan diameter 1-2 mm di mukosa bukal kanan regio gigi 43,44 (Gambar 3c-d). Tidak tampak kelainan pada mukosa labial. Coating putih tebal masih terdapat pada lidah (Gambar 3e) dan saat itu pembersihan karang gigi baru selesai dilakukan. Pasien diinstruksikan untuk berkumur dengan prednison $5 \mathrm{mg}$ yang dilarutkan dalam $10 \mathrm{ml}$ air matang tiga kali sehari selama lima hari dan direncanakan untuk penghalusan cusp gigi-gigi anterior atas dan bawah yang tajam. Namun, hingga laporan ini ditulis, pasien belum kembali ke bagian Penyakit Mulut.

\section{Pembahasan}

Pada kasus ini, diagnosis sindrom Behçet atau BD ditegakkan berdasarkan pemeriksaan subyektif dan obyektif. Pada pemeriksaan subyektif, diketahui bahwa lesi pada alat kelamin mulai timbul sejak duabelas tahun yang lalu, diikuti oleh timbulnya sariawan berulang dalam rongga mulut dan kerusakan pada mata. Umumnya, ulserasi rongga mulut merupakan "The hallmark of the disease" dan mengawali gejala sistemik lain secara bersamaan atau beberapa tahun sebelumnya. ${ }^{1,16}$ Rata-rata interval antara timbulnya ulserasi rongga mulut dengan manifestasi lainnya lebih kurang 6-8,8 tahun. ${ }^{16,17}$ Manifestasi berikutnya adalah ulser di mukosa genital lalu diikuti lesi pada mata. Pada pasien ini, diagnosis BD yang ditegakkan sudah sesuai dengan kriteria klinis berdasarkan 
ISGBD tahun 1990 yakni adanya aftosa minor rongga mulut berulang ditambah ulserasi aftosa genital dan uveitis pada mata. Penegakan diagnosis $\mathrm{BD}$ memang membutuhkan rentang waktu yang cukup lama karena kurangnya tes diagnostik yang bersifat universal, sehingga umumnya diagnosis BD ditegakkan hanya berdasarkan indentifikasi gambaran klinis yang sifatnya tipikal atau khas. ${ }^{17}$

Pada pasien ini, ulser yang ditemukan umumnya berbentuk bulat atau oval dengan diameter 2 hingga $8 \mathrm{~mm}$, dasar ulser dangkal dan berwarna putih, dikelilingi daerah eritema serta ditemukan pada daerah yang tidak berkeratin dalam rongga mulut seperti lateral lidah, mukosa bukal dan labial. Gambaran ini sangat mirip dengan stomatitis aftosa rekuren (SAR) tipe minor. Pada penelitian yang dilakukan oleh Main dkk (1992), ditemukan bahwa tidak terdapat perbedaan antara durasi, frekuensi serta onset timbulnya ulser pada BD atau SAR, namun pada BD ditemukan bahwa lesi yang muncul umumnya berjumlah enam atau lebih. Selain itu, lokasi lesi paling sering ditemukan pada palatum lunak dan orofaring, dimana lokasi ini jarang terjadi pada SAR. Ukuran ulser juga lebih bervariasi, dikelilingi daerah eritem yang lebih meluas. Daerah yang lebih eritematus ini menggambarkan adanya vaskulitis yang bersifat prominen pada BD. ${ }^{18}$

Ulserasi pada $\mathrm{BD}$ biasanya lebih sakit dan meluas, tunggal atau berkelompok, terjadi perubahan yang cepat dari bentuk ulser yang datar dan kecil membentuk ulser yang lebih luas dan dalam. Ulser dapat muncul pada lidah, gusi, mukosa bukal, palatum, tonsil serta faring. Pada $\mathrm{BD}$, ulser muncul minimal tiga episode selama duabelas bulan dan sebagian besar tidak meninggalkan jaringan sikatrik. Pola rekurensi dan remisi sangat tipikal dan lesi menjadi lebih sering muncul setelah 5 atau 7 tahun. ${ }^{1}$

Whallet dkk (1999), ${ }^{17}$ menemukan bahwa sekitar $79 \%$ pasien BD memiliki ulser aftosa tipe minor, $10 \%$ tipe mayor, namun tidak ditemukan tipe herpetiformis. Natah (2001), ${ }^{19}$ mengungkapkan bahwa ulser aftosa muncul pada $99 \%$ pasien BD dan merupakan gejala yang pertama kali muncul pada $67 \%$ pasien. Ketiga tipe SAR yakni tipe minor, mayor dan herpetiformis dapat ditemukan juga pada BD dan tidak ada gambaran spesifik yang membedakan keduanya. ${ }^{19}$ Selain SAR, complex aphtosis atau bipolar aphtosis juga merupakan bentuk yang harus dibedakan dari BD. ${ }^{15,19}$ Complex aphtosis merupakan ulserasi aftosa ulang kambuh yang hanya terdapat pada rongga mulut dan alat kelamin saja. ${ }^{15,19}$ Ulser rongga mulut umumnya multipel (lebih dari tiga) tanpa manifestasi penyakit sistemik. ${ }^{11}$ Aftae pada complex aphtosis umumnya memiliki kaitan dengan sweet's syndrome, inflammatory bowel disease dan komplikasi AIDS. ${ }^{11}$ Diagnosis banding BD adalah chronic oral aphtosis, infeksi HSV, sweet's syndrome, HLA-B27related syndrome seperti ankylosing spondylitis, eritema multiformis, pemfigoid, pemfigus, sifilis, Reiter syndrome, kolitis ulseratif dan lupus eritematosus. ${ }^{21,22}$

Berdasarkan anamnesis, diketahui bahwa ulser pada alat kelamin muncul lebih dulu dibandingkan lesi di rongga mulut. Ulser-ulser tersebut terdapat pada penis dan skrotum, terkadang dapat bertahan hingga sebulan, hilang timbul selama duabelas tahun, serta memiliki gambaran yang mirip dengan ulser rongga mulut. Mandelcorn dkk (2003) menyatakan bahwa ulser pada alat kelamin umumnya muncul pada $75 \%$ pasien, bersamaan atau setelah timbulnya ulser rongga mulut dan bertahan selama 10 hingga 30 hari. ${ }^{7,11}$ Pada pria, lesi mukosa alat kelamin terdapat pada skrotum, penis dan perianal sedangkan pada wanita terdapat pada vulva, vagina dan perianal. ${ }^{16,20}$ Ulser-ulser tersebut biasanya berbentuk tidak beraturan, dalam, serta dapat meninggalkan jaringan parut. $^{21}$

Lesi pada mata merupakan penyebab morbiditas yang paling penting pada $\mathrm{BD}$, ditandai dengan mengaburnya penglihatan, rasa sakit pada mata, fotofobia, mata merah dan berair. Lesi terjadi pada retina dan uvea. ${ }^{21}$ Keterlibatan okular meliputi sekitar 25 hingga $75 \%$ pasien dan timbul setelah adanya lesi rongga mulut. ${ }^{7,17,21}$ Mayoritas kasus BD pada mata, lesi bersifat bilateral, hanya sekitar $6 \%$ yang bersifat uniokular. ${ }^{22}$ Pada beberapa kasus, lesi pada mata timbul tanpa disertai lesi rongga mulut. $^{22}$ Pada pasien ini, lesi mata sudah 
menimbulkan komplikasi mata kanan berupa glaukoma, hingga dilakukan tindakan CCT yang bertujuan untuk mengatasi glaukoma refraktori dan mengurangi rasa sakit. ${ }^{23}$

Lesi pada kulit meliputi eritema nodusum berupa ruam nodular yang sakit dan umumnya ditemukan pada wanita pada kaki bagian depan. $^{7}$ Lesi-lesi ini umumnya dapat sembuh secara spontan, meninggalkan area pigmentasi, namun terkadang timbul ulserasi. ${ }^{21}$ Pria umumnya lebih sering mengalami pseudofolikulitis dan acneiform nodul di wajah, leher dan punggung. ${ }^{7,21}$ Pseudofolikulitis timbul akibat iritasi kulit setelah bercukur dan dapat menyebabkan timbulnya tromboflebitis lokal., ${ }^{7,21}$ Namun adanya acneiform nodul pada orang dewasa dan pasien yang sedang menjalani terapi kortikosteroid tidak dapat digunakan sebagai penentu diagnosis. ${ }^{20}$ Pada pasien ini, ditemukan nodul pada pipi kiri, namun penulis tidak dapat memastikan secara pasti apakah nodul tersebut merupakan acneiform nodule atau bukan. Tes patergi merupakan salah satu kriteria inklusi pada BD, namun tidak mutlak positif karena hanya muncul pada 40 hingga $80 \%$ pasien BD. ${ }^{20}$ Tes patergi berguna dalam mengevaluasi kemampuan kulit terhadap adanya iritasi dan termasuk kedalam kriteria diagnosis $\mathrm{BD}^{21}$ Timbulnya reaksi ini akibat akumulasi netrofil dan sel mononuklear, namun tes patergi juga positif pada penyakit sweet's syndrome dan pyoderma gangrenosum. ${ }^{21}$ Dalam kasus ini, tes patergi tidak dilakukan di bagian KulitKelamin.

Saat ini, tidak ada metode yang dianggap andal (reliable) atau memiliki standarisasi tertentu dalam mengukur tingkat keparahan BD. ${ }^{13}$ Namun, Yosipovitch dkk (1995) dalam jurnal yang dipublikasikan oleh Krause (1999), telah menyusun skala keparahan BD berdasarkan tingkat potensial morbiditas dan mortalitas penyakit. ${ }^{13} \mathrm{BD}$ termasuk tipe mild bila hanya meliputi ulserasi pada rongga mulut dan alat kelamin, lesi pada kulit, arthralgia, sakit kepala berulang, epididimitis, gangguan saluran pencernaan atau trombosis vena superfisial. ${ }^{13}$ Sedangkan BD tipe moderate meliputi artritis, trombosis vena dalam pada kaki atau perdarahan saluran pencernaan. ${ }^{13}$ BD tipe severe yakni posterior/pan uveitis, aneurisma arteri, trombosis vena mayor atau neuroBehçet. ${ }^{13}$ Pada kasus ini, BD sudah termasuk kedalam tipe severe dimana sudah terjadi ulserasi rongga mulut, alat kelamin serta panuveitis. Kebutaan mata pasien telah menurunkan kualitas hidupnya. Hal ini terlihat dari kondisi pasien yang mengaku mengalami stres akibat tidak mampu melakukan aktivitas sehari-hari dengan baik akibat gangguan penglihatan.

Pada bagian Kulit Kelamin, telah dilakukan pemeriksaan histologi dari biopsi lesi di alat kelamin. Hasil yang ditemukan tidak bertentangan dengan gambaran histopatologis BD. Menurut McCarty (2003), tidak ada temuan laboratorium yang patognomonik pada kasus BD. ${ }^{11}$ Karakteristik gambaran histopatologis BD adalah reaksi vaskular netrofilik. ${ }^{11}$ Biopsi pada lesi akut menunjukkan adanya reaksi vaskular netrofilik dengan pembengkakan endotel pembuluh darah, ekstravasasi eritrosit serta leukositoklasia atau vaskulitis leukositoklastik. 10,11 Pada lesi kronis tampak perivaskulitis limfositik. Namun, vaskulitis netrofilik merupakan gambaran histopatologis yang bersifat predominan, sehingga dapat disimpulkan bahwa diagnosis BD hanya berdasarkan temuan histologis saja tidak dapat ditegakkan tanpa disertai tampilan klinis. ${ }^{11}$

Kerusakan pada pembuluh darah, hiperfungsi netrofil dan respon autoimun merupakan karakteristik BD. ${ }^{9}$ Kerusakan pembuluh darah umumnya disertai oleh hiperkoagulabilitas akibat sel-sel endotel dan platelet yang teraktivasi. ${ }^{9}$ Pada lesi aktif termasuk lesi yang timbul saat tes patergi, terdapat banyak infiltrasi netrofil tanpa infeksi. ${ }^{9}$ Netrofil pada pasien BD menghasilkan peningkatan produksi superoksida, kemotaksis dan enzim lisosom yang berlebihan sehingga menyebabkan luka jaringan. ${ }^{9}$ Tumour Necrosis Factor (TNF) $\alpha$, interleukin (IL) $1 \beta$ dan 8 merupakan sitokin yang terlibat dalam aktivasi netrofil dan dapat meningkatkan ekspresi adesi molekul. ${ }^{9}$ Fungsi limfosit juga terganggu pada BD dimana limfosit tidak mampu mengenali Heat Shock Protein (HSP) 60 sel tubuh yang mirip dengan HSP 60 bakteri sehingga 
mengaktifkan sitokin pro-inflamatori pada lapisan endotel dan menimbulkan vaskulitis. ${ }^{21,25}$

Pemicu timbulnya BD yang paling sering ditemukan adalah agen virus infeksius, baik yang sedang berlangsung atau infeksi yang sudah lama terjadi. ${ }^{1}$ Infeksi virus dan bakteri yang mampu memicu timbulnya BD diantaranya adalah infeksi HSV, virus hepatitis, parvovirus B19, mycobacteria, Borrelia burgdorferi, Helicobacter pylori dan antigen streptokokus. ${ }^{1,7}$ Pada pasien ini, dugaan faktor pemicu yang mungkin dapat menimbulkan BD adalah infeksi HSV-2. Adanya HSP mikroorganisme dapat memicu respon autoimun reaksi silang (mimikri molekular) pada pasien dengan defek imunoregulatori. ${ }^{11}$ Defek ini menyebabkan ketidakseimbangan pertahanan tubuh anti bakterial, menimbulkan respon imun abnormal melawan mikroorganisme terutama antigen streptokokus. ${ }^{8}$

Yang menarik adalah terdapat gambaran striae-striae putih dengan pola retikular pada mukosa bukal kanan. Tampilan ini mengarah pada reaksi likenoid yang timbul akibat pemakaian obat sistemik. Berdasarkan anamnesis, diketahui bahwa pasien tidak menyadari kapan lesi tersebut mulai timbul. Saat ini, obat yang memicu timbulnya reaksi ini belum diketahui secara pasti, namun ada dugaan bahwa kondisi ini disebabkan pemakaian obat tetes mata yang rutin digunakan pasien sejak sembilan tahun yang lalu hingga saat ini. Oral lichenoid lesions (OLLs) merupakan reaksi hipersensitivitas tipe lambat akibat obat-obat sistemik, dimana paparan terjadi dalam waktu yang lama. ${ }^{26}$ Gambaran klinisnya mirip dengan oral lichen planus, unilateral, dan sembuh bila obat yang diduga sebagai penyebab dihentikan. ${ }^{23}$ Walaupun mekanisme timbulnya reaksi ini masih belum jelas, namun diduga obat tetes mata dapat menimbulkan perubahan antigenik keratinosit yang kemudian akan menstimulasi reaksi imunologi. ${ }^{26,27}$ Faktor lingkungan yang dapat mempengaruhi rekurensi dan kondisi ulserasi rongga mulut adalah sress, merokok dan trauma lokal. ${ }^{19}$ Pada pasien ini, kondisi kebersihan rongga mulut yang buruk dan kondisi gigi yang berjejal dengan permukaan gigi yang tajam dapat mengiritasi permukaan membran mukosa sehingga memudahkan timbulnya lesi.

Perawatan BD bertujuan untuk meredakan gejala yang berkaitan dengan lesi mukokutaneous dan artritis, mengendalikan peradangan, meminimalkan disabilitas fungsional dan mencegah rekurensi. ${ }^{6}$ Pemilihan perawatan tergantung pada tampilan klinis, lokasi dan keparahan lesi. Kombinasi obatobatan sangat dianjurkan karena dapat memberikan hasil yang lebih baik. ${ }^{6}$ Pada kunjungan pertama, pasien dianjurkan untuk menggunakan povidone iodine $1 \%$ dan anjuran untuk memperbaiki kesehatan rongga mulut. Pemberian obat kumur juga dikombinasi dengan anjuran melanjutkan pemakaian pasta triamcinolone acetonide $0,1 \%$ yang memang sudah digunakan oleh pasien sejak seminggu yang lalu, disertai instruksi pemakaian yang jelas. Triamcinolone acetonide $0,1 \%$ merupakan mild-potency steroid. Pasta ini diaplikasikan secara topikal sebagai anti inflamasi, bertujuan untuk menurunkan frekuensi dan keparahan lesi dengan efek samping minimal. Cara aplikasi adalah pasien diinstruksikan untuk mengoles sejumlah kecil pasta pada lokasi lesi dengan menggunakan kapas di lidi setelah makan dalam kondisi mukosa kering dan tidak makan atau minum 30 menit sesudahnya. Aplikasi dianjurkan dilakukan sebanyak 10 kali per hari dengan waktu aplikasi selama lima menit. Faktor yang diduga menambah keparahan lesi pada pasien adalah sulitnya mengaplikasikan pasta pada lokasi yang tepat karena penglihatan pasien sudah menurun dan kurangnya ketelitian saat penggunaan pasta serta mukosa tidak dikeringkan terlebih dahulu sebelum aplikasi dilakukan. Selain itu, kurangnya frekuensi aplikasi pasta juga memperlambat proses penyembuhan lesi.

Pada kunjungan kedua di bagian Penyakit Mulut, pasien diberikan steroid topikal dalam bentuk larutan kumur yakni dengan cara swish and spit. Sediaan ini memberikan keuntungan penetrasi yang baik pada ulserasi yang luas. Kerugian penggunaan sediaan ini adalah steroid akan berkontak pada seluruh permukaan mukosa dan dengan tekanan yang kuat pada 
permukaan ulserasi maka akan meningkatkan risiko efek samping. Kondisi ini juga diperparah bila larutan steroid tertelan oleh pasien. ${ }^{28}$

\section{Kesimpulan}

Penegakan diagnosis dan pemilihan perawatan yang tepat dapat menghambat atau paling tidak memperlambat perkembangan penyakit BD. Kerjasama yang baik antara berbagai disiplin ilmu di bidang kedokteran dan kedokteran gigi dibutuhkan untuk mencapai kesembuhan yang optimal dan mengurangi risiko timbulnya komplikasi.

\section{Daftar Pustaka}

1. Marshal SE. Behçet's disease. Best Pract Res Clin Rheumatol 2004;18(3):291-311. http://www.sciencedirect.com.Diunduh tanggal 10 Februari 2007.

2. Sharquie KE, Najim RA, Raghif AR. Dapsone in Behçet's disease: A double-blind, placebocontrolled, cross-over study. J Dermatol 2002;29:267-79.

3. Najim RA, Sharquie KE, Al-Janabi MH. Acetylator phenotipe in Behçet's disease. $J$ Dermatol 2003;30:464-71.

4. Kyung Kim M, Su Park K, Ki Min J, Soo Cho C, Youn Kim H. A case of polychondritis in patient with Behçet's disease. Korea J Int Med 2005;20:339-42.

5. Shek LPC, Lim DLC. Thalidomide in Behçet's disease. Biomed Pharmacother 2002;56:31-5.

6. Kaklamani VG, Kaklamanis PG. Treatment of Behçet's disease- An update. Semin Arthritis Rheum 2001;30:299-312.

7. Mandelcorn J, Bray WB, Kong HP. The management of Behçet's disease-A multidisciplinary approach. J Rheumatol 2003;80(2):94-97.

8. Yanagihori H, Oyama N, Nakamura K, Mizuki N, Oguma K, Kaneko F. Role of IL-12B promoter polymorphism in AdamantiadesBehçet's disease susceptibility: an involvement of Th1 immunoreactivity against Streptococcus sanguinis antigen. $J$ Invest Dermatol 2006;126:1534-40.Akar H, Konuralp C, Akpolat T. Cardiovascular involvement in Behçet's disease. Anadolu Kardiyol Derg 2003;3:261-5.
9. Carl W, Havens J, Kielich M. Behçet's disease: Dental and oral soft tisue complications. Quintessence Int 2000;31:113-6

10. McCarty MA, Garton RA, Jorizzo JL. Complex aphtosis and Behçet's disease. Dermatol Clin 2003;21(1):41-8.

11. Kurokawa MS, Yoshikawa H, Suzuki N. Behçet's disease. Semin Respir Crit Care Med 2004;25:557-68.

12. Krause I, Uziel Y, Guedj D, Mukamel M, Harel L, Molad Y et al. Childhood Behçet's disease: clinical features and comparison with adultonset disease. Rheumatology 1999;38:457-62.

13. Bang D. Clinical spectrum of Behçet's disease. $J$ Dermatol 2001;28:610-3.

14. Ghate JV, Jorizzo JL. Behçet's disease and complex aphtosis. $J$ Am Acad Dermatol 1999;40:1-18.

15. Rabinovich CE, Weiner LW. Behcet syndrome. http://www.emedicine.com/specialties.htm Diunduh tanggal 8 Februari 2007.

16. Whallet AJ, Thurairajan G, Hamburger J, Palmer RG, Murray PI. Behçet's syndrome: a multidisciplinary approach to clinical care. $Q \mathrm{~J}$ Med 1999;92:727-40.

17. Main D.M.G, Chamberlain M.A. Clinical differentiation of oral ulceration in behçet's disease. Br J Rheumatol 1992;31:767-70.

18. Natah SS. Recurrent aphtous ulceration. Academic dissertation 2001:10-74.

19. Neville BW, Damm DS, Allen CM, Bouquot JE. Allergies and immunologic diseases. In: Oral and maxillofacial pathology. $2^{\text {nd }}$ Edit. Philadelphia. WB Saunders 2002:290-2.

20. Sakane T, Takeno M, Suzuki N, Inaba G. Behçet's disease. N Engl J Med 1999;341(17): 1284-90.

21. Verity DH, Wallace GR, Vaughan RW, Stanford MR. Behçet's disease: from Hippocrates to the third millenium. $\mathrm{Br} \quad \mathrm{J}$ Ophthalmol 2003;87:1175-83.

22. Scully C. Handbook of oral disease. Diagnosis and management. Revised Edit. London. Martin Dunitz 2001:85-8.

23. Cyclocryotherapy. http://www.answers.com/ library/. Diunduh tanggal 8 Februari 2007.

24. Kalaycian A, Zouboulis CC. An update on Behçet's disease. JEADV 2007;21:1-10.

25. Piboonniyom SO, Treister N, Pithipat W, Woo SB. Scoring system for monitoring oral lichenoid lesions: A preliminary study. Oral Surg Oral Med Oral Pathol Oral Radiol Endod 2005;99:696-703. 
Manifestasi Behcet Dusease yang Parah

26. Colquhoun AN, Ferguson MM. An association between oral lichen planus and persistently dry mouth. Oral Surg Oral Med Oral Pathol Oral Radiol Endod 2004;98:60-8.

27. Gonzales-Moles MA, Scully C. Vesiculoerosive oral mucosal disease- Management with topical corticosteroids: (1) Fundamental principles and specific agents available. J Dent Res 2005;84(4):294-301. 